\title{
Analysis of the Behaviour of Prices of Major Staple Foods in West Africa: A Case Study of Nigeria
}

\author{
O. E. Ayinde ${ }^{1}$, T. E. Ilori ${ }^{1}$, K. Ayinde ${ }^{2}$, R. O. Babatunde ${ }^{1}$ \\ ${ }^{1}$ Department of Agricultural Economics and Farm Management University of Ilorin, Ilorin, Kwara State, \\ Nigeria \\ ${ }^{2}$ Department of Statistics, Ladoke Akintola University of Technology, Ogbomoso, Oyo State, Nigeria
}

\begin{abstract}
The study analyzed the price behavior of major staple foods in West Africa taking Nigeria as a case study (1966 - 2011). It described the trend of the major staple food prices and examined the linear relationship and interdependence of the major staple food prices in Nigeria. Secondary data were used for this study. The sources were; Food and Agriculture Organization (FAO), and National Bureau of Statistics (NBS). These data were transformed from their nominal value to real value and analyzed using descriptive statistics, unit root test, Pearson correlation coefficient, granger-causality test and structural equation model. The study revealed that the prices of most of the major staple foods were at the maximum value between 1991 and 1993 while their prices were at the minimum value between 1978 and 1983 . The study observed that the price of cowpea is most volatile seconded by maize. The results of the unit root test showed that all the variables studied were stationary. The prices of the major staple foods were linearly correlated; some were positively correlated while some were negatively correlated. Granger-causality test on the major staple foods prices showed that the prices of most staple foods were unidirectional while only few were bi-directional. The study further revealed that the prices of staple foods were interdependent. The study recommends political stability in the country as the major staple food prices reached maximum level during the period of 1993 presidential election crisis.
\end{abstract}

\section{Keywords:}

Staple food, prices, behavior, maize, rice, yams, cowpea, sorghum and cassava.

Ayinde, O. E., Ilori, T. E., Ayinde, K. and Babatunde, R. O. (2015) "Analysis of the Behaviour of Prices of Major Staple Foods in West Africa: A Case Study of Nigeria ", AGRIS on-line Papers in Economics and Informatics, Vol. 7, No. 4, pp. 3 - 17, ISSN 1804-1930.

\section{Introduction}

The agricultural sector is an important economic sector in Nigeria's economy because it plays an important role in rapid growth and development of the economy (Famoriyo, Nwagbo, 1981). Agriculture provides food for the growing population, employment for over $70 \%$ of the population, raw materials and foreign exchange earnings for the development of industries (Giroh et al., 2010). In spite of the predominance of the petroleum sector and significant dependence of Nigeria economy on this sector, agriculture remains a major source of economic resilience and mainstay (Ojo, Akanji, 1996; NEEDS, 2004).

The performance of agriculture since 1970 in Nigeria clearly showed that it contributes more than $30 \%$ of the annual Gross Domestic Product
(GDP), accounts for over $70 \%$ of the non-oil exports and provides over $80 \%$ of the food needs of the country (Adegboye, 2004). National Bureau of Statistics reported in 2008 that Agriculture contributed 42 percent of Nigeria's gross domestic product (GDP). It is the second largest export earner after crude oil and the largest employer of rural labor; thus, the sector ranks as a key contributor to wealth creation, poverty reduction and food security in the country.

However, for the past two decades, while population grew at a rate between $2.5 \%$ and $3 \%$ per annum, food production grew at a rate of about $2.5 \%$ per annum (CBN, 1999; World Bank, 2001). So, the pressure on domestic price levels persisted as the consumer prices; which reached very high levels at the end of 1993 increased further. 
It is important to note that prices are the most readily available and reliable indicator that guide farmers' planting decisions in Nigeria. Farmers are confronted with food prices that are volatile (Fafchamps, 1992). A farmer's planting decisions depend on anticipated profit which in fact depends on anticipated prices of planted crops. This has made prices an important tool in the economic analysis of markets (Momoh, Agbonlahor, 2007). In addition, at this time of historically high food prices (Anderson, Themmakoon, 2015) and increases in the uncertainty surrounding food prices is problem (Bellemare, 2015), there is a need to study to study how the prices of the major staple foods behave. Today, it is indeed disheartening and disgusting to note that a country endowed with abundant natural resources is experiencing acute starvation possibly caused by staple foods shortage and their continuous price increase. Now, the economic effect of this was that it resulted to poor health of an average Nigerian which imposes a constraint to the economic development of the country.

While most studies on agricultural product prices in Nigeria focused on vertical dynamic analysis and market integration (Olayemi, 1977; Oludimu, 1982; Adekanye, 1988; Afolami, 1998; Adeyokunnu, 1973; Ladipo, Fabiyi, 1982), it is therefore pertinent to study how the prices of the major staple foods behave so as to put in place measures that would regulate the prices in such a way that the farmers and the consumers would be better off. Based on the foregoing, this study seeks to describe the trend of the major staple food prices and also examine the price behavior of the major staple foods in Nigeria.

The findings from this study would contribute to the increased understanding of behavior of staple food prices in the economy. Also, the results from this study would be useful for the policy makers and other researchers as well.

\section{Empirical and analytical frame work}

\section{Unit Root Test}

A stationary series is one with a mean value which will not vary with the sampling period. In contrast, a non-stationary series will exhibit a time varying mean (Juselius, 2006). Before examining integration relationships between or among variables, it is essential to test for unit root, and identify the order of stationarity, denoted as I (0) or I (1). This is necessary to avoid spurious and misleading regression estimates.
Obasi (2007) used Augmented Dickey-Fuller tests for the order of integration of relative price variability and inflation. The result revealed that Inflation was not stationary at the level, but it was stationary at the first difference while food price variability was stationary at the level for the first and zero lags. Cash crops price variability was stationary at zero lag. Also, Aliyu (2008) quantitatively assessed the impact of exchange rate volatility on non-oil export flows in Nigeria through the use of Unit root tests. The empirical results showed evidence of stationarity at level for some variables while for some at first difference. In 2010 Mesike et al. conducted unit root test using ADF to test for the order of integrations of price variability of cash crops and inflation. The test was applied over the period of 1970-2008 without a time trend. The test results strongly supported the null hypothesis that price variability is I (1) or non-stationary while inflation is stationary at I (0) level. Following from this, they differenced the price variability to become stationary. Jin and Kim (2012) developed method to measure time series data that are non-stationary using South Korea price indices of crops such as rice. In determine the stationary of the data, Jin and Kim (2012) used Augmented Dickey-Fuller unit tests. Acosta (2012) also used Augmented Dickey-Fuller unit tests. Additionally, In Modeling Nigerian Government Revenues and Total Expenditure: An Error Correction Model Approach, Ayinde et al. (2013) reported the results of the unit root from the use of Phillip-Perron and Augmented Dickey-Fuller unit tests. The results showed that all the original variables were non-stationary but their first differencing was stationary. Thus, they are integrated of order one i.e. I (1).

\section{Pearson Correlation Coefficients}

Rosa and Vasciaveo (2012) employed Pearson correlation coefficients to study the relationship between Oil and Agricultural market. The study established that high correlation coefficients of the agricultural commodity prices were consistent with the high degree of integration among agricultural markets; showing that a shock to an agri-commodity price might have an influence on other agri-commodities prices.

Emakoro and Ayantoyinbo (2014) studied market integration and price variation in rice marketing in Osun state using Pearson Correlation Coefficients. The Pearson correlation coefficients revealed high and significant correlation of the price series which indicated co-movement in the prices. The positive correlation showed that an increase in the retail 
price in one market would follow the price increase in the other market.

Ibironke (2014) also employed Pearson Correlation Coefficients in a study titled how effective is the Nigerian Oil-Price-Based Fiscal Rule. The study showed that there was negative association between the real government expenditure and real oil revenue after the introduction of fiscal rule.

\section{Granger-Causality Test}

The Granger causality analysis was proposed by Granger in 1969. The Granger causality test uses a one-sided distributed lag where by the incremental forecasting value of past (often plus present) history of one variable on another variable is used as the yardstick. It stated that, " $Y_{t}$ is causing $X_{t}$ if the formal is better able to predict the later using all available information".

In Granger (1969) bi-variate framework, $X$ is said to cause $Y$ if the past plus the current values of $X$ facilitate the forecasting of $Y$ when employed in conjunction with the past value of

$Y$ as compared with when only past values of $Y$ are employed. This means that some information must be contained in the past and current $X$ values which are absent in the past $Y$ values. To examine the incremental forecasting value; regress the current $Y$ value on the past $Y$ values plus present and past $X$ values. Causation from $X$ to $\mathrm{Y}$ is identified if the coefficient of the present and past $X$ values are significantly different from zero as a group. The appropriate significance test is the conventional statistical F-test.

Granger-Causality model is based on the assumption that $X$ and $Y$ are jointly covariance stationary which is a rather strong assumption concerning economic time series. To make the series more stationary therefore, the original data are often first-differenced or seasonal - differenced and it has been shown by Pierce and Haugh, (1977) that such linear transpirations still preserve any causality that may be present in the original data.

Many studies had been carried out using grangercausality model but only the recent ones are discussed. Ayinde et al. (2010) empirically study climate change and agricultural production in Nigeria using granger causality test. The Granger causality test revealed that change in rainfall (climatic parameter) positively affects agricultural production in Nigeria. Also, research conducted using granger-causality model by Olatunji et al. (2012) revealed there was unidirectional causation from inflation to agricultural output change, thus inflation in Nigeria depends on agricultural output change during the time frame.

Rosa and Vasciaveo (2012) applied the grangercausality test to the study of Agri-Commodity Price Dynamics: The relationship between Oil and Agricultural Market. The study established that no causal effect between the Oil (Brent) of Italian agric-commodities and united state agric-model but joining the two markets, there was causal effect. Also, in analysis of market integration and price variation in rice marketing, Emakoro and Ayantoyinbo (2014) reported that some markets granger-cause each other while some did not granger-cause.

\section{Materials and methods}

\section{Study Area}

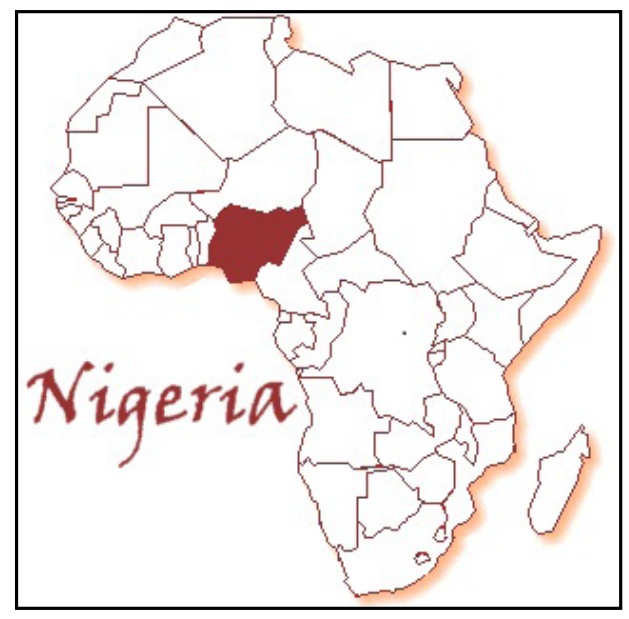

Source: Nokculture 2010

Figure 1: Map of Africa showing Nigeria

The study area is Nigeria (Fig. 1). It is officially the Federal Republic of Nigeria, is a federal constitutional republic comprising 36 states and its Federal Capital Territory, Abuja. The country is located in West Africa and shares land borders with the Republic of Benin in the west, Chad and Cameroon in the east, and Niger in the north. It shares a 4,047 kilometers $(2,515 \mathrm{mi})$ border with Benin $(773 \mathrm{~km})$, Niger $(1497 \mathrm{~km})$, Chad $(87 \mathrm{~km})$, Cameroon $(1690 \mathrm{~km})$, and has a coastline of at least $853 \mathrm{~km}$. Nigeria lies between latitudes $4^{\circ}$ and $14^{\circ} \mathrm{N}$, and longitudes $2^{\circ}$ and $15^{\circ} \mathrm{E}$. Its coast in the south lies on the Gulf of Guinea on the Atlantic Ocean and rainfall is between 20 and 60 inches (508 and 1,524 $\mathrm{mm}$ ) per year. Agriculture used to be the principal foreign exchange earner of Nigeria. At one time, Nigeria 
was the world's largest exporter of groundnuts, cocoa, and palm oil and a significant producer of coconuts, citrus fruits, maize, pearl millet, cassava, yams and sugar cane. About 60\% of Nigerians work in the agricultural sector, and Nigeria has vast areas of underutilized arable land.

\section{Sources and collection of data}

Secondary data were used for this study. The times series data from year 1966 to 2011 was collected from different sources because of different crops and prices involved in the study. The sources were: World Bank Database, Food and Agriculture Organization (FAOSTAT), Central Bank of Nigeria (CBN), National Bureau of Statistics (NBS) and Federal Ministry of Agriculture and Rural Development (FMARD). In carrying out this study, six major staple foods were purposively selected as they are among the food products of majority of the population in Nigeria and even in African countries. The selected major staple foods were maize, cassava, cowpea, yams, sorghum and rice. For each staple food selected, data on price over forty years (1966-2011) were collected from World Bank Database, Food and Agriculture Organization (FAOSTAT), Central Bank of Nigeria (CBN), National Bureau of Statistics (NBS) and Federal Ministry of Agriculture and Rural Development (FMARD).

\section{Analytical techniques}

The data were analyzed using descriptive statistics, Pearson correlation coefficient and Grangercausality test. The statistical packages employed were Eviews 8, Gretl and SPSS 16 and Stata 10 (statistical software) and statistical processes were employed in order to achieve an appropriate analysis. To deal with national currency fluctuations, which might cause price to look as though they are integrated; all prices were quoted in naira per tonne ( /tonne) and series of prices were all deflated by using Consumer Price Index (CPI). The real prices obtained were then used for the analyses.

Real Price $=\frac{\text { Nominal Price }}{\text { Consumer Price Index }} \times 100$

\section{Descriptive statistics}

Descriptive statistics such as graphs, mean, minimum, maximum and standard deviation were employed to achieve the specific objective one (1) stated earlier. They were used to describe the trend of the price of each of the selected major staple foods.

\section{Unit Root Test, Pearson Correlation and Granger Causality Models}

Unit root test was conducted to test for the stationarity of staple food prices while the Pearson price correlation coefficient and Granger Causality test were used to examine the price relationship of major staple foods in Nigeria, 1966 - 2011. These models were adapted from Ravallion (1986), Mohammad (2005), Ayinde et al. (2010) and Emakoro and Ayantoyinbo (2014).

\section{Unit Root Test}

The unit root test is the most widely adopted test of stationarity or non-stationarity over the past year which is mainly conducted on time series data. Test of the stationarity of the variables is paramount to avoid a spurious result. There are several methods for testing the presence of unit roots. The most widely used method is Augmented Dickey-Fuller (ADF). This method was employed in this study (Gujarati, 2003). The unit root model is stated below.

$$
\delta X_{t}=\alpha+\delta X_{t-1}+\sum_{k=1}^{p} \beta \delta X_{t-k}+\varepsilon_{t}
$$

Where:

$X_{t}=$ price at time $\mathrm{t}$

$\delta=$ first difference operator

$t=$ time indicator

$\varepsilon_{t}=$ the error term

$\delta$, $\alpha$ and $\beta=$ parameters to be estimated

$k=$ number of lag of the price variables to be included.

\section{Pearson Correlation Coefficients}

Pearson correlation coefficients were used to examine the strength of price linkages among the major staple foods. Given the price series of each staple food at time $t, X_{t}$ and $Y_{t}$, the degree of linear association between the staple foods were measured by the sign and magnitude of the correlation coefficient, $r$. The model is stated below.

$r=\frac{\sum_{i=1}^{n}\left(\left(X_{i}-\bar{X}\right)\left(Y_{i}-\bar{Y}\right)\right)}{\sqrt{\sum_{i=1}^{n}\left(X_{i}-\bar{X}\right)^{2} \sum_{i=1}^{n}\left(Y_{i}-\bar{Y}\right)^{2}}}$

Where:

$r=$ Pearson price correlation coefficient,

$X_{i}$ and $Y_{i}=$ price variables at time $\mathrm{t}$

$\bar{X}$ and $\bar{Y}=$ mean of the variables 


\section{Granger Causality Test}

The Granger Causality test was adopted to further examine the relationship of major staple food prices. It was used to provide additional evidence as to whether and in which direction price of staple food cause one another.

Where

$n=$ number of observation

$m=$ number of lag

$Y_{t}=$ price of a particular staple foods (maize, cowpea, cassava, sorghum, rice or yams)

$X_{t}=$ price of staple food (maize, cowpea, cassava, sorghum, rice or yams)

$\varepsilon_{t}=$ error term

$\alpha$ and $\beta=$ parameters to be estimated.

This model is adapted from Rosa and Vasciaveo (2012) and Emakoro and Ayantoyinbo (2014).

\section{Choice of Lag Length}

To choose lag Length, a rule of thumb is to compute ACF (Autocorrelation Function) up to one-third $(1 / 3)$ to one-quarter $(1 / 4)$ the length of the time series. The statistical criterion such as Akaike and Schwarz information criterion were then used to select the optimal lag length.

AIC and SIC were reported because they impose harsher penalty than $\overline{\mathrm{R}}^{\wedge} 2$ (adjusted $\mathrm{R}$ square) for adding more regressors. In comparing models, the model with lowest value of AIC and SIC is preferred.

\section{Structural Equation Model (SEM)}

Structural equation model consisted of more than one equation for each of the jointly endogenous variables. The model for this study as adapted from Babatunde and Qaim (2010) is specified below.

$$
\begin{aligned}
\ln P_{\text {yam }}= & \alpha_{0}+\beta_{1} \ln P_{\text {cas }}+\beta_{2} \ln P_{\text {cow }}+\beta_{3} \ln P_{\text {ric }} \\
& +\beta_{4} \ln P_{\text {maz }}+\beta_{5} \ln P_{\text {sor }}+\varepsilon_{1} \\
\ln P_{\text {maz }}= & \alpha_{1}+\beta_{6} \ln P_{\text {cas }}+\beta_{7} \ln P_{\text {cow }}+\beta_{8} \ln P_{\text {ric }} \\
& +\beta_{9} \ln P_{\text {yam }}+\varepsilon_{2} \\
\ln P_{\text {cow }}= & \alpha_{2}+\beta_{10} \ln P_{\text {cas }}+\beta_{11} \ln P_{y a m}+\varepsilon_{3} \\
\ln P_{\text {cas }}= & \alpha_{3}+\beta_{12} \ln P_{y a m}+\varepsilon_{4} \\
\ln P_{\text {ric }}= & \alpha_{4}+\beta_{13} \ln P_{\text {cas }}+\beta_{14} \ln P_{\text {cow }}+\beta_{15} \ln P_{\text {maz }} \\
& +\beta_{16} \ln P_{\text {yam }}+\varepsilon_{5}
\end{aligned}
$$

$$
\begin{aligned}
\ln P_{\text {sor }}= & \alpha_{5}+\beta_{17} \ln P_{\text {cas }}+\beta_{18} \ln P_{\text {cow }}+\beta_{19} \ln P_{\text {ric }} \\
& +\beta_{20} \ln P_{\text {maz }}+\beta_{21} \ln P_{\text {yam }}+\varepsilon_{6}
\end{aligned}
$$

Where:

$P_{\text {yam }}=$ price of yams $=($ per tonne $)$

$P_{\text {maz }}=$ price of maize ( per tonne)

$P_{c a s}=$ price of cassava ( per tonne)

$P_{\text {cow }}=$ price of cowpea ( per tonne)

$P_{r i c}=$ price of rice ( per tonne)

$P_{\text {sor }}=$ price of sorghum ( per tonne)

$\alpha_{0}-\alpha_{5}=$ intercepts

$\beta_{1}-\beta_{21}=$ structural parameters or coefficients

Note: The model was fitted based on the grangercausality test results and theoretical ground. This was done to identify each equation in the model. Identification of each equation in the equation system was necessary to obtain numerical estimates of the parameters of the structural equation from the estimated reduced-form coefficients. Some of the equations in the model were exactly identified while some were over-identified.

The procedures for equation identification were stated below;

If $k=g-1$, the equation is exactly identified.

If $k>g-1$, the equation is over-identified.

If $k<g-1$, the equation is under-identified (Maddala, 2001).

Where:

$k=$ number of excluded endogenous variable plus excluded exogenous variable.

$g=$ number of endogenous variable in the system.

\section{Results and discussion}

This section deals with the presentation, interpretation and discussion of data collected for the study after being analyzed. The study uses figures (graphs) and tables to present the results for easy understanding.

Description of the trend of the major staple food prices in Nigeria (1966 - 2011)

The graphs 1 to 6 describe the trend of major staple food prices in Nigeria over the studied periods. The lowest and highest prices of each staple food were identified and the study also discussed the trend of staple food for the past five years being the recent prices. This is done to know how the prices of staple food would behave for at least the next five years. 


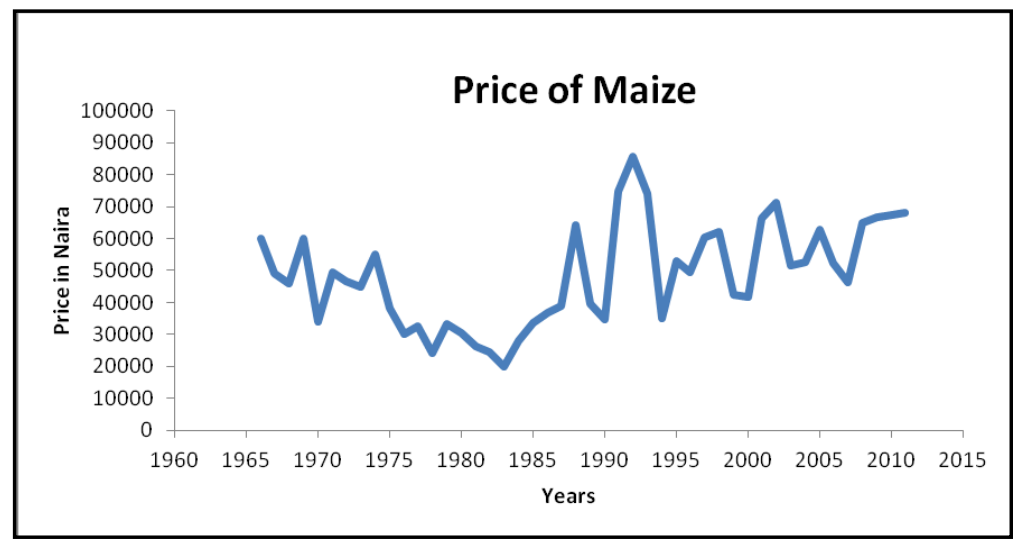

Source: Author's illustration using data from FAOSTAT, 2014

Graph 1: Trend of price per tonne of maize in Nigeria (1966-2011).

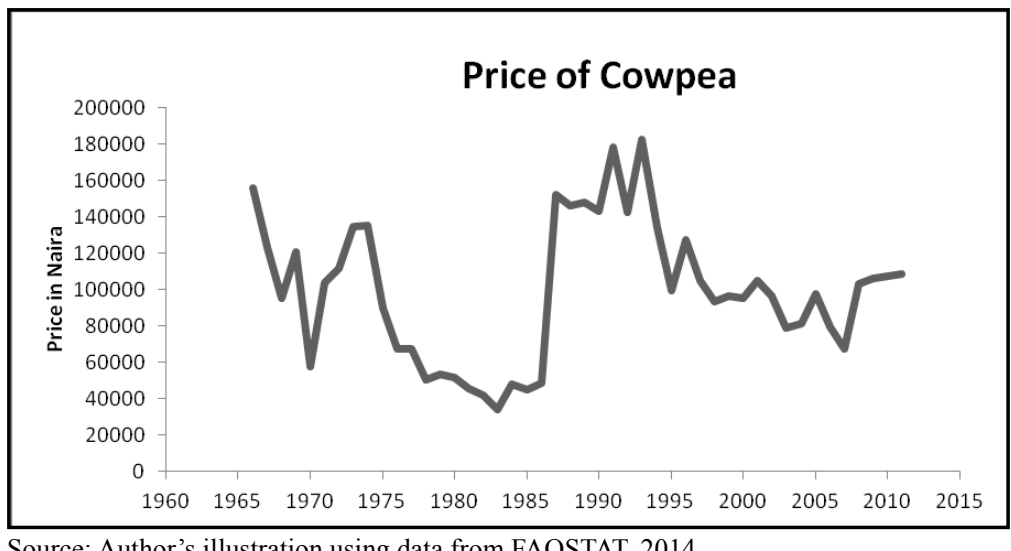

Source: Author's illustration using data from FAOSTAT, 2014

Graph 2: Trend of price per tonne of cowpea in Nigeria (1966-2011).

Graph 1 shows the price of maize in Nigeria from 1966 to 2011. The price of maize moved in a zigzag manner over the period under study. The trend line equation is $y=535.0 x-1 E+06$. The price fluctuated between the lowest value of 19,853 in 1983 and highest value of $\$ 85,821$ in 1992 with the mean of $\$ 4.84 \mathrm{E} 4$ and standard deviation of 15931.055. Considering last five years price movement, it is observed that the price of maize increased sharply from 46285.81 in 2007 to 64784.24 in 2008 followed by gradual increase in 2009 ( 66583.1), 2010 ( $67321.25)$ and 2011 ( $\$ 68241.87)$.

Graph 2 shows the price of cowpea in Nigeria from 1966 to 2011. The price of cowpea fluctuated over the period under study. The trend line equation is $y=169.8 x-23866$. The price moved from the lowest amount of 34,222 in 1983 to the highest amount of 182,612 in 1993 with the mean of 9.9E4 and standard deviation of 37984.804. In the last five years, the price of cowpea rose sharply from 67104.6 in 2007 to 103235.8 in 2008 and then by gradually increased in 2009 ( 106102.4), 2010 ( 107278.6) and 2011 (108745.7).

Graph 3 represents the price of cassava in Nigeria from 1966 to 2011. The price of cassava varied over the period under the studied periods. The trend line equation is $y=20796-89.04 x$. The price moved from the minimum value of 12,845 in 1981 to the maximum value of $\$ 52,684$ in 1985 with the mean of $\mathrm{N} \mathrm{3.09E4}$ and standard deviation of $8,813.615$. It is observed there was a sharp fall in cassava price between 1984 and 1985 . The sharp fall in price of cassava in 1985 might due to effectiveness of agricultural policies and fiscal policies during that period. In the last five years, it was observed that the price of cassava rose slightly from 19252.15 in 2007 to 26436.36 in 2008 and then by steady increase in 2009 ( 27170.42), 2010 ( 27471.62) and 2011 (27847.29).

Graph 4 depicts the price of rice in Nigeria from 1966 to 2011. The price of rice swung over the period study period. The trend line 


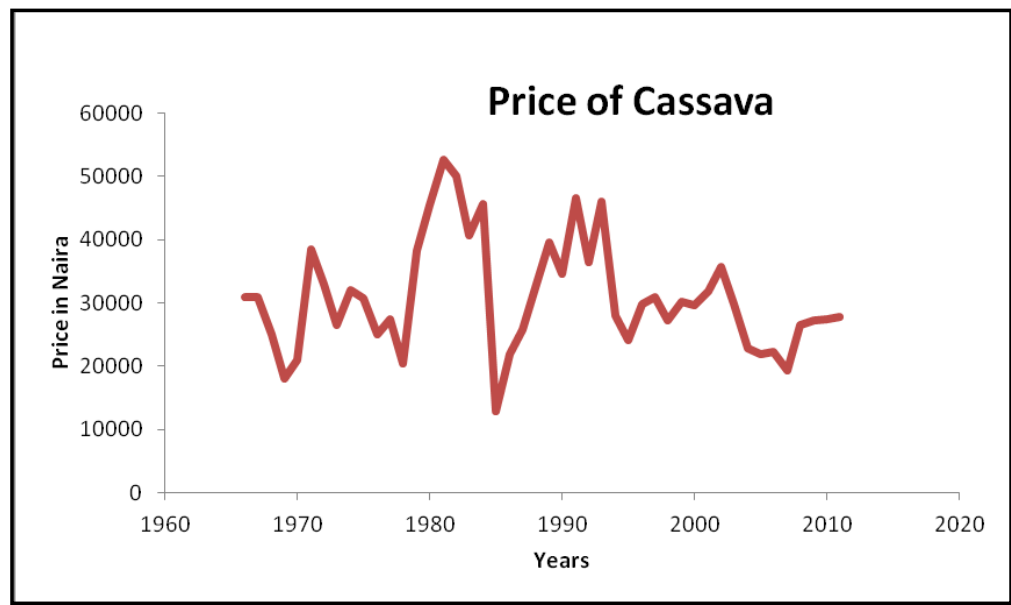

Source: Author's illustration using data from FAOSTAT, 2014

Graph 3: Trend of price per tonne of cassava in Nigeria (1966-2011).

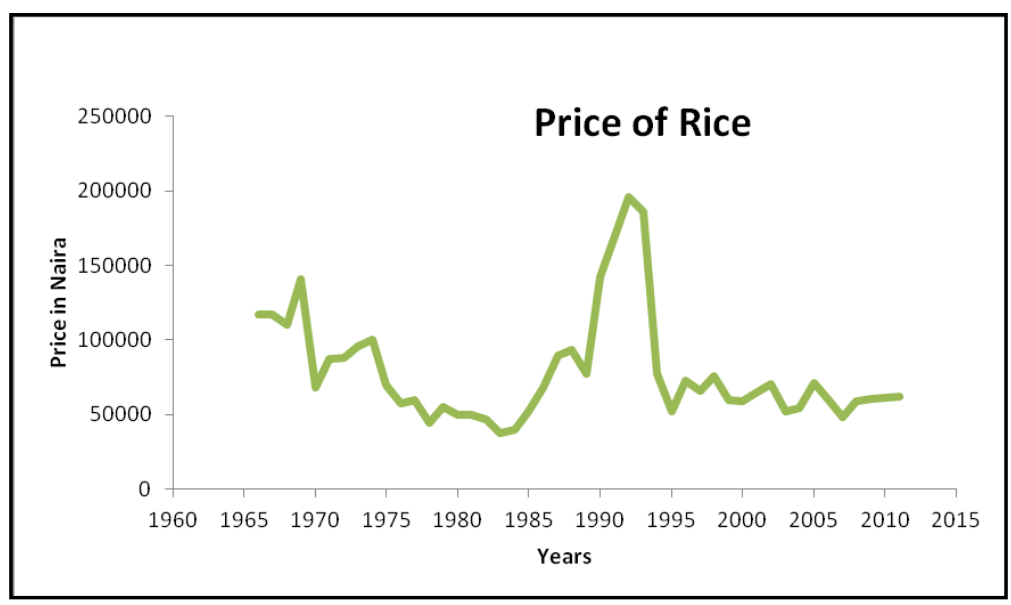

Source: Author's illustration using data from FAOSTAT, 2014

Graph 4: Trend of rrice per tonne of rice in Nigeria 1966 - 2011.

equation is $\mathrm{y}=1 E+06-613.3 x$. The price moved from the lowest value of 37,814 in 1983 to the highest value of 196,202 in 1992 with the mean of 7.91E4 and standard deviation of 37077.565 . It is observed that the price of rice was relatively low before the sudden increase which reached the highest value in 1992. Then, the price fell sharply in 1994 after slight falling in 1993. After which the price fluctuated slightly from 1994 to 2011.

Graph 5 shows the price of sorghum in Nigeria from 1966 to 2011. The price of sorghum undulated over the period under study. The trend line equation is $y=649.3 x-1 E+06$. The price fluctuated between the lowest value of $\$ 20,480$ in 1978 and $\$ 82,096$ in 1991 with the mean of $4.55 \mathrm{E} 4$ and standard deviation of 15631.532. In the last five years, it is observed that the price of sorghum increased sharply from 35353.46 in 2007 to 62427.08 in 2008 then, followed by steady increase in 2009 ( 64160.49), 2010 ( 64871.75) and 2011 ( 65758.92).

Graph 6 illustrates the price of yams in Nigeria from 1966 to 2011. The price of yams varied over the period studied. The trend line equation is $y=784.6 x-1 E+06$. The price moved from the minimum value of 22,342 in 1978 to the maximum value of 116,262 in 1993 with the mean of $\$ 6.34 \mathrm{E} 4$ and standard deviation of 18095.685 . It is observed that within last five years the price continued increasing steadily.

Table 1 shows the minimum, maximum, mean and standard deviation of the major staple food prices. The study reveals that price of cowpea is most volatile among all the major staple food prices next by rice price. This means that the prices of cowpea and rice changed often 


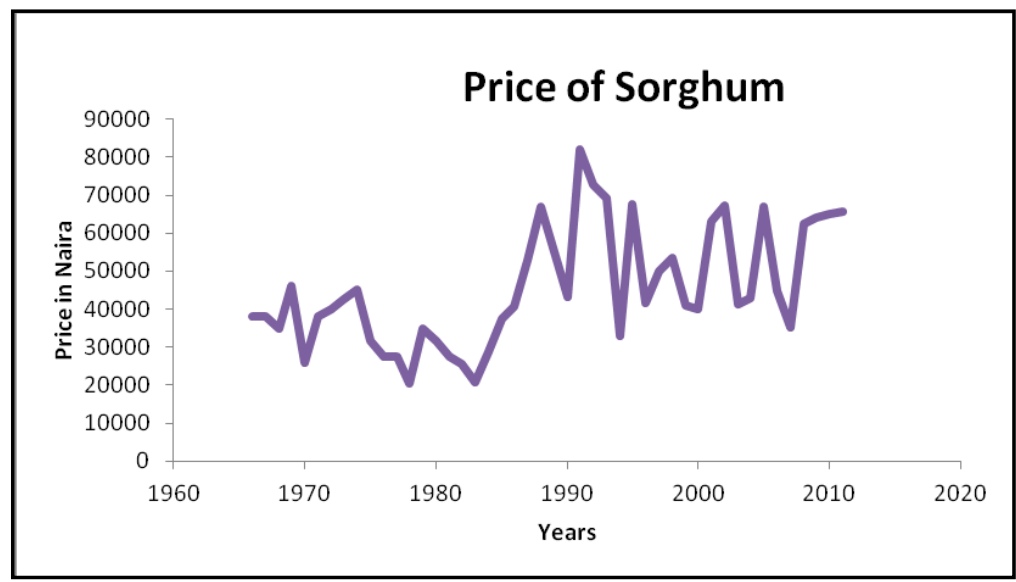

Source: Author's illustration using data from FAOSTAT, 2014

Graph 5: Trend of price per tonne of sorghum in Nigeria 1966 - 2011.

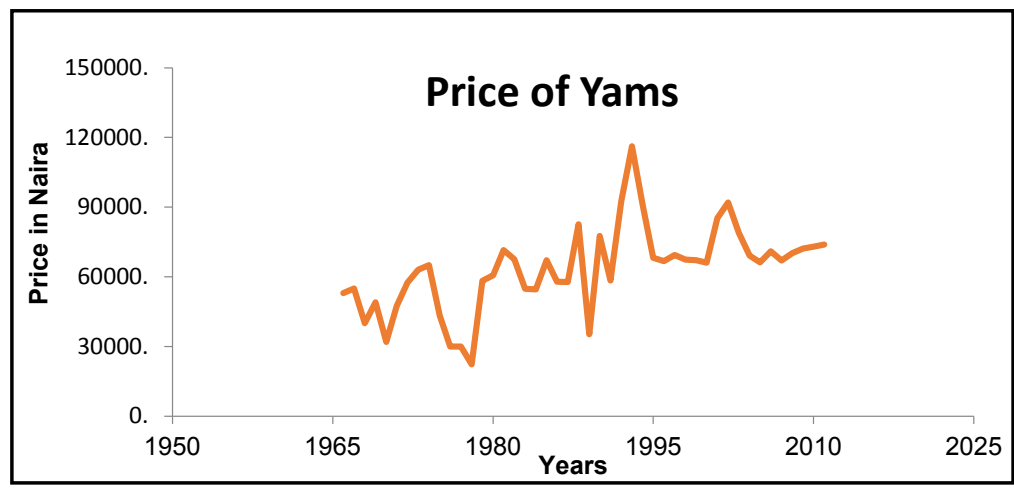

Source: Author's illustration using data from FAOSTAT, 2014

Graph 6: Trend of price per tonne of yams in Nigeria $(1966-2011)$.

\begin{tabular}{|l|r|r|r|r|}
\hline $\begin{array}{l}\text { Major staple } \\
\text { foods }\end{array}$ & $\begin{array}{c}\text { Minimum price } \\
\text { per tonne (N) }\end{array}$ & $\begin{array}{c}\text { Maximum price } \\
\text { per tonne (N) }\end{array}$ & $\begin{array}{c}\text { Mean price } \\
\text { per tonne (N) }\end{array}$ & Std deviation \\
\hline Maize & $19,853(1983)$ & $85,821(1992)$ & 484000 & $15931.055\left(5^{\text {th }}\right)$ \\
\hline Cowpea & $34,222(1983)$ & $183,612(1993)$ & 991000 & $37984.804\left(1^{\text {st }}\right)$ \\
\hline Cassava & $12,845(1985)$ & $52,684(1981)$ & 30900 & $8813.615\left(6^{\text {th }}\right)$ \\
\hline Rice & $37,814(1983)$ & $196,202(1992)$ & 791000 & $37077.565\left(2^{\text {nd }}\right)$ \\
\hline Sorghum & $20,480(1978)$ & $82,096(1991)$ & 45500 & $15631.532\left(4^{\text {th }}\right)$ \\
\hline Yams & $22,342(1978)$ & $116,262(1993)$ & 63400 & $18095.685\left(3^{\text {rd }}\right)$ \\
\hline
\end{tabular}

Source: Author's Computation using data from FAOSTAT, 2014

Table 1: Descriptive statistics of major staple food prices.

over the periods under study and the implication of this is that it could be difficult to predict the future prices of these crops. The high volatility of cowpea price could be due to constant fluctuations in its production - a consequence of climate variability and insect infestation while that of rice could be due to low rice production in the country and in the effort to augment rice production with imports, the rice price becomes more volatile. The implication of this is that many local farmers are being discouraged to increase their production since they have become the price takers and is even difficult for them to predict the next year price. Conversely, the volatility of cassava price is the lowest among the studied major staple food prices next by price of maize. The less volatility of cassava price might due to the fact Nigeria is the world leading cassava producer and thereby the effect of external factors on its price is minimal. The finding of this study supported the earlier studies on the analysis of incentives and disincentives for cassava in Nigeria and effect 
of Climate Variability on Agricultural Production and Innovation in Guinea Savannah Region of Nigeria (FAO, 2013 and Ayinde et al., 2013).

The Price Relationship of the Major Staple Foods in Nigeria

\section{Unit Root Test on the price of major staple foods in Nigeria}

The Augmented Dickey-Fuller (ADF) unit root tests were carried out on all the variables of the analysis. One lag was used for the random walk regressions of major staple food prices because they are annual series and any autocorrelation problems they might have are expected to be corrected after one period. The results are presented in table 2 .

The results of stationarity test for the staple food prices using Augmented Dickey-Fuller (ADF) unit roots tests indicated that the variables were all stationary at their levels and first differencing, precisely at lag 1 except price of rice that was stationary at lag six. This finding corroborates earlier findings that food commodity price series are mostly stationary of order 1 i.e. I (0) (Chirwa, 2000, Mafimisebi, 2008, Desi, 2012, Ojiako, 2012; Emakoro, Ayantoyinbo, 2014).

\section{Linear Relationship of Prices of major staple foods in Nigeria}

The Correlation between the staple food prices for the period of study is estimated to determine the level of the linear relationship. The Pearson correlation coefficients among the price series signal the positive or negative linear correlation between the staple food prices. It suggests the co-movements between the price series. The high correlation coefficients of some staple food prices are consistent with the high degree of integration among staple food markets; showing that a shock to a staple food price may have an influence on other staple food prices. This supports the earlier findings of Emakoro and Ayantoyinbo (2014) which revealed that the positive correlation of food markets showed an increase

\begin{tabular}{|l|c|c|l|}
\hline Major staple foods & Level with drift & $\mathbf{1}^{\text {st }}$ difference with drift & Remarks \\
\hline RPMAIZE & $-3.225^{* *}$ & $-7.801^{* * *}$ & Stationary \\
\hline RPCOWPEA & $-2.865^{*}$ & $-8.358^{* * *}$ & Stationary \\
\hline RPCASSAVA & $-3.655^{* * *}$ & $-8.352^{* * *}$ & Stationary \\
\hline RPRICE & $-2.645^{*}$ & $-4.666^{* * *}$ & Stationary \\
\hline RPSORGHUM & $-3.498^{* *}$ & $-7.780^{* * *}$ & Stationary \\
\hline RPYAMS & $-3.362^{* *}$ & $-9.211^{* * *}$ & Stationary \\
\hline
\end{tabular}

Note: $* * *$ indicates stationarity at $1 \%$; ** points to stationarity at $5 \%$ of significance, and * indicates stationarity at $10 \%$ level of significance

Source: Author's computation using data from FAOSTAT, 2014

Table 2: Unit Root Test on the price of major staple foods in Nigeria.

\begin{tabular}{|l|l|l|l|l|l|l|}
\hline Staple food prices & & & & & & \\
\hline Maize & Maize & Cowpea & Cassava & \multicolumn{1}{|c|}{ Rice } & Sorghum & Yams \\
\hline Cowpea & 1 & $0.640^{* * *}$ & -0.074 & $0.540^{* * *}$ & $0.882^{* * *}$ & $0.551^{* * *}$ \\
\hline & & 0 & -0.624 & 0 & 0 & 0 \\
\hline Cassava & & 1 & 0.085 & $0.766^{* * *}$ & $0.645^{* * *}$ & $0.359^{* *}$ \\
\hline & & & -0.574 & 0 & 0 & -0.014 \\
\hline Rice & & & 1 & 0.176 & 0.16 & 0.228 \\
\hline & & & & -0.242 & -0.914 & -0.128 \\
\hline Sorghum & & & & 1 & $0.462^{* * *}$ & $0.286^{*}$ \\
\hline & & & & & -0.001 & -0.054 \\
\hline Yams & & & & & 1 & $0.567 * * *$ \\
\hline & & & & & & 0 \\
\hline & & & & & & 1 \\
\hline
\end{tabular}

Note: $* * *$ indicates $1 \%$ level of significance; $* *$ indicates $5 \%$ level of significance;

* indicates $10 \%$ level of significance

Source: Author's computation using data from FAOSTAT, 2014

Table 3: Results of Pearson Correlation Coefficients of Prices of Major Staple Foods (1966-2011). 
in the retail price of rice in one market would follow the price increase in the other market. The results are shown in table 3 .

Table 3 shows the linear relationships among major staple food prices under study. The study shows that all the major staple food prices are positively correlated except Maize-Cassava prices that were negatively correlated (-0.074). The negative correlation might due to the fact that maize and cassava compete for the available farm resources when planted on the same piece of land (i.e. mixed cropping system which is common in Nigeria). This means that increase in the production one leads to decrease in the production of the other; this could be responsible for the negative correlation of their prices. The positive correlation indicates that an increase in the price of one staple food would lead to increase in the prices of the other staple foods but at different degrees since their Pearson correlation coefficients differ while negative correlation indicates that an increase in the prices of one staple would lead to decrease in the other staple food prices. The Pearson correlation coefficients of major staple food prices are statistically significant at $1 \%, 5 \%$ and $10 \%$ levels except the prices of maize-cassava, cowpea-cassava, cassava-rice, cassava-sorghum and cassavayams. The study further reveals that the Pearson correlation coefficient ( $r$ ) of Maize-Sorghum is the highest ( 0.882$)$ followed by that of cowpea-rice (0.766). This might be due to the fact that maize and sorghum crops are substitute commodities, meaning that if the price of maize increases the demand for sorghum increases which could later cause the price of sorghum to rise and vice versa. Cowpea-Cassava prices have the lowest Pearson correlation coefficient which is not even significant at various statistical significant levels considered. This implies that if the price of cowpea increases, it would not cause any immediate change in the price of cassava and vice versa.

\section{Linear Granger Causality Test of the prices of major staple foods in Nigeria}

Granger causality-test was carried out to study how a particular staple food price influences the other. The results of granger causality test are presented along with some optimal lag length indicators. The Akaike Information Criterion and Schwarz information criterion were used to select the optimal lag length. The results are presented in Table 4.

The granger causality test was used to determine the influence of staple food prices on one another. It provides additional evidence as to whether and in which direction the price of staple food relate. The results in table 5 suggest that the direction of causality is unidirectional in most of the staple food prices while direction of causality is bilateral in few staple food prices. The study reveals that the price of cassava granger-cause (influences) the prices of cowpea (0.0389), maize (0.0053), rice $(0.0071)$ and sorghum (0.0393) while the cassava price does not granger-cause the price of yams; the price of cowpea granger-cause the prices of maize (0.0227), yams (0.0265), sorghum (0.0053) and rice $(0.0021)$ while cowpea price does not granger-cause the price of cassava; the price of yams granger-cause the prices of maize (0.0663), cowpea (0.0237), sorghum (0.0032), cassava $(0.0962)$ and rice $(0.0046)$ while cowpea price does not granger-cause the the price of maize granger-cause the prices of rice (0.0680), sorghum $(0.1009)$ and yams (0.0718) while maize does not granger-cause the prices of cassava and cowpea; the price of rice granger-cause the prices of maize (0.0234), yams (0.0939) and sorghum (0.0048) while the rice price does not granger-cause the prices of cowpea and cassava and the price of sorghum granger cause price of yams $(0.0765)$ only. The study further discovers that there is bilateral causality between yams-cowpea, rice-maize, rice-yams, sorghum-yams and yamsmaize.

In the previous discussion, the study has established that staple food prices were linearly correlated and also granger-cause each other. However, the mechanisms through which this relationship occurs were not completely clear. This is therefore shown in table 5.

The coefficients in rows 1 of table 5 shows that if the prices of cassava and sorghum increase by 1 each, the price yams would increase by 0.34 and 0.54 respectively. The coefficients in row 2 shows 1 increase in each price of yams and cowpea would lead to 0.39 and 0.49 increases in the price of maize while \# 1 increase in the price of cassava would lead to 0.27 decreases in the price of maize. Row 3 shows that the 1 increase in each price of yams and rice would increase the price of cowpea by 0.24 and 0.81 respectively. Row 4 the price of cassava would increase by 0.29 if the price of yams increases by let say $\$ 1$. Row 5 shows that if the price of cowpea increases by $¥ 1$, the price of rice would increase by $\$ 0.71$. Row 6 reveals that N 1 increase in each price of yams, maize and cowpea would increase the price of sorghum by $0.19, \$ 0.71$ and $\$ 0.19$ 


\begin{tabular}{|c|c|c|c|c|c|c|}
\hline Staple Food Prices & F-stat & P-value & AIC & SIC & $\begin{array}{c}\text { Optimal } \\
\text { lag length }\end{array}$ & $\begin{array}{c}\text { Direction } \\
\text { of causality }\end{array}$ \\
\hline Cowpea $\rightarrow$ Cassava & 1.0438 & 0.4452 & 772.8119 & 788.921 & & \\
\hline Cassava $\rightarrow$ Cowpea & 2.6245 & $0.0389 * *$ & 866.3466 & 882.4558 & 9 & Unidirectional \\
\hline Maize $\rightarrow$ Cassava & 0.7045 & 0.6845 & 792.6254 & 807.3637 & & \\
\hline Cassava $\rightarrow$ Maize & 3.9697 & $0.0053 * * *$ & 836.865 & 851.6032 & 8 & Unidirectional \\
\hline Rice $\rightarrow$ Cassava & 0.2019 & 0.9907 & 772.8119 & 788.921 & & \\
\hline Cassava $\rightarrow$ Rice & 3.8583 & $0.0071 * * *$ & 853.7516 & 869.8607 & 9 & Unidirectional \\
\hline Sorghum $\rightarrow$ Cassava & 0.5777 & 0.8138 & 732.7927 & 751.4569 & & \\
\hline Cassava $\rightarrow$ Sorghum & 2.9213 & $0.0393 * *$ & 780.0093 & 798.6735 & 11 & Unidirectional \\
\hline Yams $\rightarrow$ Cassava & 2.4876 & $0.0962 *$ & 917.1351 & 922.4877 & & \\
\hline Cassava $\rightarrow$ Yams & 0.852 & 0.4343 & 974.7034 & 980.056 & 2 & Unidirectional \\
\hline Yams $\rightarrow$ Cassava & 0.8643 & 0.5821 & 754.0736 & 771.4923 & & \\
\hline Cassava $\rightarrow$ Yams & 2.6932 & $0.0407 * *$ & 804.1819 & 821.6006 & 10 & \\
\hline Maize $\rightarrow$ Cowpea & 0.9796 & 0.4784 & 887.277 & 902.0153 & & \\
\hline Cowpea $\rightarrow$ Maize & 2.9373 & $0.0227 * *$ & 836.865 & 851.6032 & 8 & Unidirectional \\
\hline Rice $\rightarrow$ Cowpea & 0.81752 & 0.6181 & 841.1902 & 858.6089 & & \\
\hline Cowpea $\rightarrow$ Rice & 5.27341 & $0.0021 * * *$ & 833.0882 & 850.5069 & 10 & Unidirectional \\
\hline Sorghum $\rightarrow$ Cowpea & 0.6273 & 0.7696 & 841.1902 & 858.6089 & & \\
\hline Cowpea $\rightarrow$ Sorghum & 4.37107 & $0.0053 * * *$ & 801.5198 & 850.5069 & 10 & Unidirectional \\
\hline Yams $\rightarrow$ Cowpea & 2.96585 & $0.0237 * *$ & 866.3466 & 882.4558 & & \\
\hline Cowpea $\rightarrow$ Yams & 2.8889 & $0.0265 * *$ & 826.8647 & 842.9739 & 9 & Bi-directional \\
\hline Rice $\rightarrow$ Maize & 2.97614 & $0.0234 * *$ & 817.5269 & 833.6361 & & \\
\hline Maize $\rightarrow$ Rice & 2.25344 & $0.0680^{*}$ & 853.7516 & 869.8607 & 9 & Bi-directional \\
\hline Rice $\rightarrow$ Sorghum & 4.02671 & $0.0048 * * *$ & 862.4564 & 875.7649 & & \\
\hline Sorghum $\rightarrow$ Rice & 1.24164 & 0.3197 & 896.8658 & 910.1743 & 7 & Unidirectional \\
\hline Rice $\rightarrow$ Yams & 2.02203 & $0.0939^{*}$ & 868.7869 & 882.0954 & & \\
\hline Yams $\rightarrow$ Rice & 4.04395 & $0.0046^{* * *}$ & 898.8658 & 910.1743 & 7 & Bi-directional \\
\hline Sorghum $\rightarrow$ Maize & 1.63996 & 0.1722 & 857.6418 & 870.9503 & & \\
\hline Maize $\rightarrow$ Sorghum & 1.97695 & $0.1009^{*}$ & 862.4564 & 875.7649 & 7 & Unidirectional \\
\hline Sorghum $\rightarrow$ Yams & 2.15017 & $0.0765^{*}$ & 846.9475 & 861.6858 & & \\
\hline Yams $\rightarrow$ Sorghum & 4.35532 & $0.0032^{* * *}$ & 842.4066 & 857.1449 & 8 & Bi-directional \\
\hline Yams $\rightarrow$ Maize & 2.24285 & $0.0663 *$ & 857.6418 & 870.9503 & & \\
\hline Maize $\rightarrow$ Yams & 2.19159 & $0.0718^{*}$ & 868.7869 & 882.0954 & 7 & Bi-directional \\
\hline
\end{tabular}

Note: $\rightarrow$ means non Granger causality hypothesis. $* * * * * / *$ denote statistical significance at $1 \%, 5 \%$ and $10 \%$ level, respectively. The optimal lag length was selected by Akaike Information Criterion (AIC) and Schwarz Information Criterion (SIC).

Source: Author's computation using data from FAOSTAT, 2014

Table 4: Pair-wise Granger Causality Test for major staple food prices. 


\begin{tabular}{|l|c|l|l|l|l|l|}
\hline & \multicolumn{6}{|c|}{ Staple Fod Prices } \\
\hline Variables & $\ln P_{\text {yam }}$ & $\ln P_{\text {maz }}$ & $\ln P_{\text {cow }}$ & $\ln P_{\text {cas }}$ & $\ln P_{\text {ric }}$ & $\ln P_{\text {sor }}$ \\
\hline Constant & 2.5455 & $3.1203^{* *}$ & 0.6727 & $9.1399^{* * *}$ & 2.3639 & -0.2736 \\
& $(1.9398)$ & $(1.5348)$ & $(1.9143)$ & $(1.5591)$ & $(1.9056)$ & $(1.1636)$ \\
\hline $\ln P_{\text {yam }}$ & & 0.1918 & -0.1658 & $0.2977^{* *}$ & -0.0506 & $0.5438^{* *}$ \\
& & -0.2681 & -0.1841 & -0.1409 & -0.1618 & -0.2549 \\
\hline $\ln P_{\text {maz }}$ & 0.3899 & & $0.4933^{* * *}$ & $-0.2652^{* *}$ & 0.037 & \\
& -0.1056 & & -0.1235 & -0.1132 & -0.1294 & \\
\hline $\ln P_{\text {cow }}$ & $0.2385^{*}$ & & & -0.0939 & $0.8120^{* * *}$ & \\
& -0.1266 & & & -0.1407 & -0.1021 & \\
\hline $\ln P_{\text {cas }}$ & $0.2962^{* *}$ & -0.364 & & & & 0.1691 \\
& -0.1595 & -0.2618 & & & & -0.2781 \\
\hline $\ln P_{\text {ric }}$ & -0.1082 & 0.0538 & $0.7116^{* * *}$ & 0.1279 & & \\
& -0.1459 & -0.188 & -0.1358 & -0.1439 & & \\
\hline $\ln P_{\text {sor }}$ & $0.1879 * *$ & $0.7048^{* * *}$ & $0.1879^{*}$ & 0.3691 & -0.1088 & \\
& -0.8805 & -0.1128 & -0.1052 & -0.8711 & -0.0936 & \\
\hline $\bar{R}^{2}$ & 0.4304 & 0.6677 & 0.6413 & 0.1171 & 0.6201 & 0.831 \\
\hline
\end{tabular}

Notes: The number of observations in this structural equation model is $\mathrm{N}=46$. Figures in parentheses are std. Error $*, * *, * * *$ indicates significant level at the $10 \%, 5 \%$ and $1 \%$ level, respectively.

Source: Author's computation using data from FAOSTAT, 2014

Table 5: Interdependence of Staple Food Prices in Nigeria.

respectively. Summarily, table 5 establishes that prices of staple food interdependent i.e. increase in price of staple food causes simultaneous changes in the prices of the others and vice versa.

\section{Conclusion}

The study concluded that the price of cowpea is most volatile seconded by maize. The results of the unit root test showed that all the variables studied were stationary. The prices of the major staple foods were linearly correlated; some were positively correlated while some were negatively correlated. Granger-causality test on the major staple foods prices showed that the prices of most staple foods were unidirectional while only few were bi-directional. The study further revealed that the prices of staple foods were interdependent.

It is therefore recommended the government should ensure political stability. This is necessary because most of the staple foods recorded highest prices between 1991 and 1993 which could be traced to the period when the country experienced serious political crisis (i.e. 1993 Presidential Election Crisis).

Corresponding author:

Dr. Opeyemi Eyitayo Ayinde

Department of Agricultural Economics and Farm Management University of Ilorin

P.M.B.1515, Ilorin, Kwara State, Nigeria

E-mail: opeayinde@yahoo.com

\section{References}

[1] Acosta. A. Measuring Spatial Transmission of White Maize Prices between South Africa and Mozambique: An Asymetric Error Correction Model Approach. African Journal of Agriculture and Resource Economics. 2012, Vol. 7, No.1, p. 1-13. ISSN 19930-3738.

[2] Adegboye, R. O. Land Agriculture and Food Security in Nigeria". Faculty Lecture Delivered at the University of Ilorin, Faculty of Agriculture, $25^{\text {th }}$ February 2004.

[3] Adekanye, T. O. Readings in Agricultural Marketing, Longman Publishers Nigeria, 1998. 
[4] Adeyokunnu, T. O. Marketing Margins for Rice in Egba Division of Western State. Bulletin of Rural Economics and Sociology. 1973, p. 253. ISSN 0007-5078.

[5] Afolami, C.A. Marketing Price Behaviour for Pepper (Capsicum Fratescens) in Oyo State Nigeria. Proc. $16^{\text {th }}$ HORTSON Conference, UNAAB, Abeokuta, 7-10 ${ }^{\text {th }}$ September, 1998.

[6] Aliyu, S. U. R. Exchange Rate Volatility and Export Trade in Nigeria: An Empirical Investigation. 2008. MPRA Paper No. 13490.

[7] Anderson, K., Thennakoon, J. Food Price pike and Poor, Small Economies: What Role for Trade Policies. African Journal of Agriculture and Resource Economics. 2015, Vol.10, No. 1, p. 16 -31. ISSN 1993-3738.

[8] Ayinde, O. E., Ajewole, O. O., Ogunlade, I., Adewumi, M. O. Empirical Analysis of Agricultural Production and Climate Change: A Case Study of Nigeria. Journal of Sustainable Development in Africa. 2010, Vol. 12, No. 6, p. 275-283. ISSN 1520-5509.

[9] Ayinde, K., Bello, A. A., Ayinde, O. E. Modeling Nigerian Government Revenues and Total Expenditure: An Error Correction Model Approach. A Paper delivered at African Association of Agricultural Economics (AAAE) Conference, 2013, Tunisia.

[10] Ayinde, O. E., Ojehomon, V. E. T., Daramola, F. S., Falaki, A. A. Evaluation of the Effects of Climate Change on Rice Production in Niger state, Nigeria. Ethiopian Journal of Environmental Studies and Management 2013:6 Supplement [Online] Available: http://dx.doi.org/10.4314/ejesm. v6i6.7S [Accessed 25 Sept 2014]. ISSN 1998 - 0507.

[11] Babatunde, R. O., Qaim, M. Impact of Off-Farm Income on Food Security and Nutrition in Nigeria. Food Policy. 2010, Vol. 35, No. 4, p. 303-311. ISSN 0306-9192.

[12] Bellemare, M. F. Rising Food Prices, Food Price Volatility, and Social Unrest. American Journal Agricultural Economics. 2015, Vol. 97, No. 1, p. 1-21. ISSN 0002-9092.

[13] Central Bank of Nigeria. CBN Annual Statement and Statement of Account. Garki, Abuja, Nigeria 1999.

[14] Chirwa, E. W. Food Marketing Reforms and Integration of Maize and Rice Markets in Malawi. Working Paper at the School of Economics, University of East, Anglia; 2000

[15] Desi, A., Yulius, J. Integration of Rice Market Inter-Provinces of Rice Production Center in Indonesia. International Conference on Environment, Energy and Biotechnology IPCBEE 2012, No. 33, p. 42-51.

[16] Emokaro, C. O., Ayantoyinbo, A. A. Analysis of Market Integration and Price Variation in Rice Marketing in Osun State, Nigeria. American Journal of Experimental Agriculture 2014, Vol. 4, No.5. [Online] Available: SCIENCEDOMAIN International www.sciencedomain.org [Accessed 10 Aug 2014]. ISSN 2231-0606.

[17] Fafchamps, M. Cash Crop Production, Food Price, Volatility and Rural Market Integration in the Third World. American Journal Agricultural Economics. 1992, Vol. 72, No. 1, p. 90-99. ISSN 0002-9092.

[18] Famoriyo, S., Nwagbo, E. C. Problems of Agricultural Finance in Nigeria. In Ojo M. O. et al.: Agricultural Credit and Finance in Nigeria: Problems and Prospects. Lagos, Central Bank of Nigeria 1981. p. 50-57.

[19] Food and Agriculture Organization. The state of Food and Agriculture. FAO, United Nations, Rome 2013. [Online] Available: www.fao.org publications [Accessed 12 Dec 2014].

[20] Giroh, D. Y.; Waizah, Y., Umar, H. Y. Technical Efficiency and Cost of Production among Gum Arabic Farmers in Jigawa State, Nigeria. Report and Opinion 2010, Vol. 2, No.1 p. 52-57. ISSN 1553-9873.

[21] Granger, C. W. J. Forecasting white noise. In: A Zellner (Ed.): Applied Time Series Analysis of Economic Data. Washington, DC: Bureau of the Census, 1983, p. 308-314. 
[22] Granger, C. W. J., Weiss, A. A. Time Series Analysis of Error-Correcting Models. In: Studies in Econometrics, Time Series, and Multivariate Statistics. New York: Academic Press, 1983. p. 255-278. ISBN-10 1483241319.

[23] Gujarati, D. N. Basic Econometrics. 2003, $3^{\text {rd }}$ ed., New York: McGraw-Hill. ISBN 0-07-233542-4.

[24] Gujarati, D. N., Porter, D. C. Basic Econometrics, 2009, 5 ${ }^{\text {th }}$ edition, New York, McGraw-Hill International. ISBN-10 0071276254.

[25] Ibironke, A. B. How effective is the Nigerian Oil-Price-Based Fiscal Rule? A Paper Presented at the Center for the Study of African Economies (CSAE) 2014, University of Oxford.

[26] Jim, H. J., Kim, T. Structural Changes in the Time Series of Food Prices and Volatility Measurement. American Journal Agricultural Economics. 2012, Vol. 94, No. 4, p. 929-944. ISSN 0002-9092

[27] Juselius, K. The Co-integrated VAR Model: Methodology and Applications, 2006. Oxford University Press.

[28] Maddala, G. S. Introduction to Econometrics 2001, $3^{\text {rd }}$ ed. Published by John Wiley \& Sons ltd. ISBN 0-02-374545-2.

[29] Mafimisebi, T. E. Long-run price integration in the Nigerian Fresh fish market: Implication for development, Delhi Business Review 2008, Vol. 9, No. 1, p.13-18. ISSN 0972-222X.

[30] Mesike, C. S., Okoh, R. N, Inoni, O. E. Impact of Inflation and Government Agricultural Policies on Relative Price variability of Cash Crops in Nigeria. Report and Opinion 2010, Vol. 2, No. 5. ISSN 1553-9873.

[31] Mohammad, S. Supply response analysis of major crops in different agro-ecological zones in Punjab. Pakistan Journal of Agricultural Research 2005, Vol., 124, No. 54, p. 144-156. ISSN 0251-0480.

[32] Momoh, S., Agbonlahor, M. U. Food Price Differences and Market Integration in Oyo State. An International Journal Asset Series C. 2007, Vol. 2, No.1, p. 79-86. ISSN 1595-9694.

[33] Nyanko, M. H. Agriculture as a major foreign exchange earner: issues and implications. National Pilot Paper. 2006, Vol. 3, No. 26, p.19.

[34] Obasi, O. U. Relative Price Variability and Inflation: Evidence from the Agricultural Sector in Nigeria. African Economic Research Consortium (AERC) 2007, Research Paper 171. ISBN 9789966778160.

[35] Ojiako, I. A., Ezedinma, C., Asumugha, G. N. ,N kang, N. M. Spatial Integration and Price Transmission in Selected Cassava Products' Markets in Nigeria: A Case of Lafun. World Applied Sciences Journal. 2012, Vol. 18, No. 9, p. 1209-1219. ISSN 1818-4952.

[36] Ojo, M. O., Akanji M. Responsiveness of Selected Agricultural Export Commodities to Exchange Rate Devaluation in Nigeria. An Econometric Analysis. CBN Economic and Financial Review 1996, Vol. 34, No. 2, p. 511-578. ISSN 1957-2968.

[37] Ladipo, O. O., Fabiyi, Y. L. An Analysis of the Structure of Fish Marketing and Distribution in Kwara State of Nigeria. Paper presented at the $3^{\text {rd }}$ Annual Conference of Fisheries Society of Nigeria, FISON, 1982, p. $40-46$.

[38] Olatunji, G. B., Omotesho, O. A., Ayinde, O. E and Adewumi, M. O. Empirical Analysis of Agricultural Production and Inflation Rate in Nigeria (1970-2006) Agrosearch 2012, Vol. 12, No. 1, p. 21 - 30. [Online] Available: http://dx.doi.org/10.4314/agrosh.v.12i1.2 [Accessed 15 Nov 2014]. ISSN 1117-9996.

[39] Olayemi, J. K. A Statistical Analysis of Price Spreads for Some Nigerian Food Commodities. Journal of Rural Economics and Development. 1977, Vol. 2, No.1. ISSN 2372-4315.

[40] Oludimu, O. The Marketing of Processed Cassava in Nigeria: An Insight. Nigeria Journal of Development Studies 1982, 2, No. 1, p. 93-102. ISSN 0189-2614. 
[41] Pierce, D. A., Haugh, L. D. Causality in Temporal System: Characterization and a Survey, Journal of Econometrics. 1977, Vol. 5, p. 265-293. ISSN 0304-3076.

[42] Ravallion, M. Testing market integration. American Journal of Agricultural Economics. 1986, Vol. 68, p. 102-109. ISSN 002-9092.

[43] Rosa, F., Vasciaveo, M. Agri-Commodity Price Dynamics: The Relationship between Oil and Agricultural Market. A Paper presented at the International Association of Agricultural Economists (IAAE) Triennial Conference, Foz do Iguaçu, Brazil, 18-24 August, 2012.

[44] World Bank. World Development Report. Oxford: Oxford University Press. 2001.

[45] Ya'aishe, M, Putai, J. A., Petu-Ibikunle, A. M. An economics analysis of cowpea production among women farmers in Askira/Uba LGA of Borno State, Nigeria". African Journal of General Agriculture 2010, Vol. 6, No. 1.

[46] Yusuf, Y. The Role of the Public Sector in making Agriculture Economically Viable, Economic Summit, Arewa House Kaduna 2004. 